\title{
The Agronomic Techniques as Determinants of the Phenolic Content and the Biological Antioxidant Effect of Palm-Tree Kale
}

\author{
Francesca Danesi*, Veronica Valli, Simona Elementi, Luigi Filippo D’Antuono
}

Department of Agri-Food Sciences and Technologies, University of Bologna, Cesena, Italy.

Email: ${ }^{*}$ francesca.danesi@unibo.it

Received November $30^{\text {th }}, 2013$; revised December $30^{\text {th }}$, 2013; accepted January $7^{\text {th }}, 2014$

Copyright (C) 2014 Francesca Danesi et al. This is an open access article distributed under the Creative Commons Attribution License, which permits unrestricted use, distribution, and reproduction in any medium, provided the original work is properly cited. In accordance of the Creative Commons Attribution License all Copyrights (C) 2014 are reserved for SCIRP and the owner of the intellectual property Francesca Danesi et al. All Copyright (C) 2014 are guarded by law and by SCIRP as a guardian.

\section{ABSTRACT}

The content of phytochemicals in vegetables is strongly affected by genetic, agronomic, and environmental factors, and by transportation and storage conditions, potentially affecting the sensory and putative health-promoting properties. In this study the impact of different agricultural techniques on the phenolics content and antioxidant activity of extracts from a traditional Italian kale landrace, called palm-tree kale (Brassica oleracea L., ssp. acephala DC, var. sabellica L.) was evaluated. Furthermore, the antioxidant effects of the different extracts were assessed in a biological system using primary cultures of neonatal rat cardiomyocytes. The final aim was to evidence whether and how the agronomic practices can affect the antioxidant properties of kale not only in vitro but also in cells. Results herein reported underline the influence of the crop production strategies in establishing the potential health benefits of a vegetable. This research approach could be useful for the selection of production techniques that are able to provide edible vegetables with higher functional activity, and evidences the need to study the food domain as a whole with the nutrition domain, and to integrate all results in order to have an overall "foodomics" vision allowing the improvement of health and well-being.

\section{KEYWORDS}

Kale; Brassica oleracea L.; Cultured Cardiomyocytes; Antioxidants; Phytochemicals; Agronomic Techniques; Plant Density; Nitrogen Fertilization

\section{Introduction}

The content of phytochemicals in vegetables is strongly affected by genetic, agronomic, and environmental factors, and by transportation and storage conditions [1,2], potentially affecting the sensory and putative health-promoting properties.

Brassica vegetables are rich in many bioactive compounds, including ascorbic acid, carotenoids, glucosinolates, and phenolics [3], which are supposed to exert positive effects in the human organism [4,5]. Most of the studies on health-promoting compounds in Brassica vegetables have focused on glucosinolates, organic sulphur compounds that, besides determining the organoleptic

"Corresponding author. characteristics, also possess biological activities such as antioxidant [6] and antitumor activity [7]. However, it is still uncertain if the beneficial effects of Brassica vegetables are ascribable to glucosinolates or to the complex of their phytochemicals profile [8].

The main objective of this research was to evidence possible differences in the protective effect of extracts derived from a traditional variety of kale, namely palmtree kale, grown with different agronomic techniques. Kale is a primitive leafy Brassica oleracea form. Palmtree kale (Brassica oleracea L., ssp. acephala DC, var. sabellica L.) is a kale landrace cultivated in some Italian areas of inland Tuscany and northern Apennines, where it is used as food, both raw and cooked. It's appreciated for its dark green color and peculiar taste [9]. 
Kale has a high health-beneficial potential value due to its richness in antioxidative compounds, including polyphenols and phenolic acids [3,10]. Total phenolic content in fresh edible parts of kale has been reported to be more than 2-fold higher than in Brussels sprouts, cauliflower, and broccoli [11]; moreover, kale has been reported to exhibit the highest antioxidant capacity within the Brassicaceae family.

The variability in the composition of kale types in relation to agronomic and environmental factors has been seldom investigated [12-14], with almost no reference to activity measured in biological systems. In this study we measured the total antioxidant capacity (TAC) and total phenolic content (TPC) of different aqueous palm-tree kale extracts, then their biological activity was verified by supplementing them to primary cultures of neonatal rat cardiomyocytes. The potential protective activity of kale extracts was assessed in both normal conditions and after an oxidative damage induced by cell exposure to $\mathrm{H}_{2} \mathrm{O}_{2}$, and was compared to the effect of a well-known antioxidant, $\alpha$-tocopherol (TC), considered the most important endogenous antioxidant in cardiac cells [15].

\section{Materials and Methods}

\subsection{Materials}

All chemicals, reagents, and solvents were purchased from Sigma-Aldrich Co. (St Louis, MO, USA) unless otherwise stated. $\alpha$-tocopherol (TC) was dissolved in ethanol at a concentration of $5 \mathrm{mM}$ and kept-at $0 \quad{ }^{\circ} \mathrm{C}$ until further use.

Palm-tree kale seeds were obtained by a local seed company based in Cesena (Italy) and directly sown in the open field in March, in the experimental farm of the University of Bologna, Cadriano (Italy). The soil of the site is classified as a fine silty, mixed, mesic Udic Ustochrepts and has a silty loam texture, with 380,375 , and $245 \mathrm{~g} \cdot \mathrm{kg}^{-1}$ of sand, silt and clay, respectively. The $\mathrm{pH}(1$ : 2.5 soil: water) is 7.9 and organic carbon is $8.5 \mathrm{~g} \cdot \mathrm{kg}^{-1}$. A base fertilization of $80 \mathrm{~kg} \cdot \mathrm{ha}^{-1} \mathrm{P}_{2} \mathrm{O}_{5}$ and $50 \mathrm{~K}_{2} \mathrm{O}$ was applied, pre-sowing. No phytochemicals or irrigation were applied. The experimental theses were:

- two planting densities: 1 plant $\mathrm{m}^{-2}$, corresponding to the plant population of traditional, handpicked, crops (low, traditional density-TD); 240 plants $\mathrm{m}^{-2}$, corresponding to the density adopted in mechanized industrial crops (high density-HD);

- nitrogen fertilization in both density plots: a dose of $160 \mathrm{~kg} \cdot \mathrm{ha}^{-1}$ nitrogen $(160 \mathrm{~N})$; a higher density plot was unfertilized thesis (0N) (Table 1 ).

The plots were arranged in a randomized block experimental design with three replications. Fully developed leaves were individually harvested at the vegetative stage
Table 1. Experimental treatments.

\begin{tabular}{ccc}
\hline & Plant density & Nitrogen fertilization \\
\hline HD-0N & 240 plant $\mathrm{m}^{-2}$ & $0 \mathrm{~kg} \mathrm{~N} \mathrm{ha}^{-1}$ \\
HD-160N & 240 plant $\mathrm{m}^{-2}$ & $160 \mathrm{~kg} \mathrm{~N} \mathrm{ha}^{-1}$ \\
TD-160N & 1 plant $\mathrm{m}^{-2}$ & $160 \mathrm{~kg} \mathrm{~N} \mathrm{ha}^{-1}$ \\
\hline
\end{tabular}

in June, immediately frozen, and lyophilized.

\subsection{Extraction of Bioactives from Plant Material}

Twenty g of lyophilized leaves, ground to a fine powder in a mill, were mixed by magnetic stirrer with $500 \mathrm{~mL}$ of boiling water and then filtered over no. 1 filter paper (Whatman Europe, UK). The filtrates were freeze-dried at $5 \mathrm{mmHg}$ pressure and at $-50{ }^{\circ} \mathrm{C}$ and then dissolved to solubilize the amount of lyophilized extract derived from $100 \mathrm{mg}$ of fresh leaves in $1 \mathrm{~mL}$ of sterile ultrapure water (Milli-Q; Millipore; Bedford, CT, USA). The obtained solutions were filtered on $0.20 \mu \mathrm{M}$ filters (Whatman) and then used for further experiments.

\subsection{Analysis of Plant Extracts}

Total phenolic content (TPC) of the hydrophilic extracts was determined according to Heimler et al. [16]. TPC was calculated by comparison with a standard curve prepared using gallic acid. The results were expressed as micrograms of gallic acid equivalents (GAE) per mg of extract.

Total antioxidant capacity (TAC) was evaluated using the method of Re et al. [17], as previously described [18]. Briefly, TAC was measured as the quenching of the absorbance at $734 \mathrm{~nm}$ (DU730 spectrophotometer; Beckman Coulter Inc., CA, USA). Values obtained for each sample were compared to the concentration-response curve of the standard trolox solution, and TAC was expressed as micromoles of trolox equivalents (TE) per mg of extract.

\subsection{Cell Culture}

Primary cultures of cardiomyocytes were obtained from the ventricles of newborn Wistar rats according to the method of Yagev et al. [19]. The investigation conforms to the Guide for the Care and Use of Laboratory Animals published by the US National Institutes of Health (NIH Publication 85-23, revised 1996). Cells were isolated and cultured as previously described [18]. At seeding, the culture medium was replaced with a fresh one containing two different concentrations of kale extract solution (10 or $20 \mu \mathrm{L} \cdot \mathrm{mL}^{-1}$ medium), or $20 \mu \mathrm{M} \mathrm{TC}$. Unsupplemented (US) cells received fresh medium with no added extract. Media were changed every $48 \mathrm{~h}$, the last medium change being $48 \mathrm{~h}$ before the experiments. 
At complete confluence in a monolayer, in some cells the medium was discarded and Earle's balanced salt solution (EBSS; pH 7.4), containing $0.1 \mathrm{mM}$ of hydrogen peroxide, was added to induce an oxidative insult, while other cells received EBSS without $\mathrm{H}_{2} \mathrm{O}_{2}$ (basal condition). After $1 \mathrm{~h}$, EBSS was removed and collected for the determination of lactate dehydrogenase activity, then cardiomyocytes were washed three times with $0.9 \% \mathrm{NaCl}$, and cell proliferative activity was assayed.

\subsection{Lactate Dehydrogenase (LDH) Release}

Cardiomyocyte plasma membrane integrity was assessed by measuring the LDH release in the EBSS. After centrifugation, to clear up the sample (250.g for $4 \mathrm{~min})$, enzyme activity was determined spectrophotometrically by using the LDH assay kit (Sigma-Aldrich Co.; St. Louis, MO, USA) according to Legrand et al. [20]. Results were expressed as percentage of US cells in basal condition, assigned as $100 \%$.

\subsection{Cell Proliferative Activity}

Cell proliferative activity was measured using the 3-(4,5dimethyldiazol-2-yl)-2,5-diphenyltetrazolium bromide (MTT) colorimetric assay [21]. The test was carried out as described previously [18]. Results were expressed as percentage of US cells in basal condition, assigned as $100 \%$.

\subsection{Statistical Analysis}

Data are the means of at least three samples obtained from different cell cultures. Statistical differences were assessed by the one-way analysis of variance (ANOVA) with Tukey's HSD or Dunnett's test, considering p < 0.05 as statistically significant.

\section{Results}

The TPC and the TAC of the different extracts are reported in Table 2. The phenolic content of HD-0N and HD-160N extracts was almost identical, and higher than TD-160N extract. The phenolic content observed in TD$160 \mathrm{~N}$ extract is in agreement with the results reported by Hagen et al. [12] who detected a phenolic content of $\approx 17$ mg GAE g ${ }^{-1}$ for a curly kale cultivar sown with a plant density similar to TD. In correspondence to a lower TPC, TD-160N extract showed lower TAC with respect to high density plots.

In basal condition, kale extracts supplementation to cardiomyocytes did not cause any modification in LDH release, apart from a slight increase in cells supplemented with the TD-160N extract at the lowest dose (Figure 1(a)). As well, cell proliferative activity was not modified by the supplementation of extracts at the lowest concentra-
Table 2. Total phenolic content (TPC) and total antioxidant capacity (TAC) of palm-tree kale extracts.

\begin{tabular}{|c|c|c|}
\hline & TPC ( $\mu g$ GAE $\left.\mathrm{mg}^{-1}\right)$ & TAC $\left(\mu \mathrm{mol}\right.$ TE $\left.\mathrm{mg}^{-1}\right)$ \\
\hline HD-0N & $30.45 \pm 0.02^{\mathrm{a}}$ & $231.91 \pm 9.18^{\mathrm{a}}$ \\
\hline HD-160N & $29.68 \pm 0.13^{\mathrm{a}}$ & $211.00 \pm 7.03^{b}$ \\
\hline TD-160N & $19.25 \pm 0.51^{b}$ & $123.54 \pm 8.00^{c}$ \\
\hline
\end{tabular}

Data are mean \pm SD of 3 samples in each group. Statistical analysis was carried out by the one-way ANOVA $(p<0.001)$ with multiple pairwise comparisons according to Tukey's HSD test: different letters indicate statistical significance (at least $\mathrm{p}<0.05$ ).
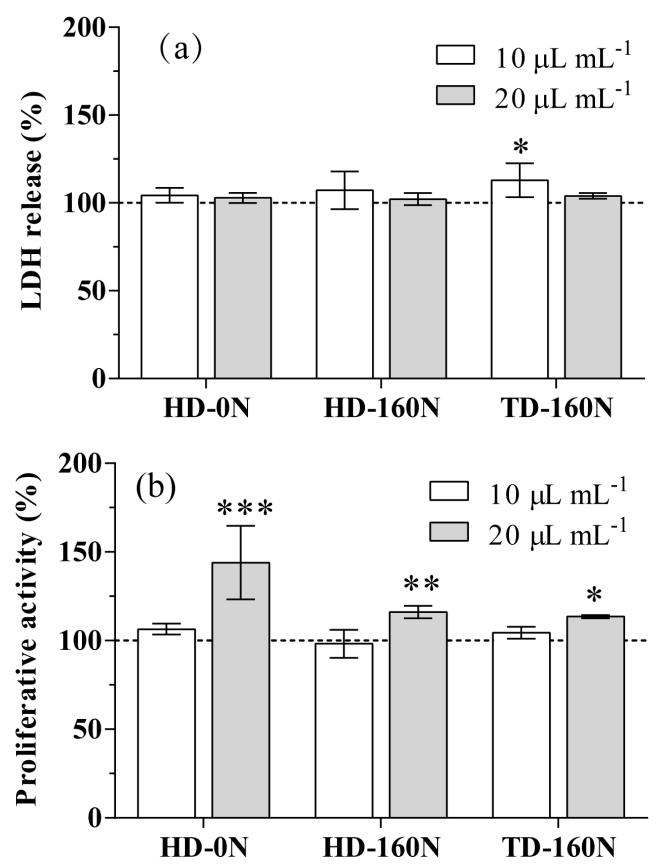

Figure 1. LDH release (a) and proliferative activity (b) in cardiomyocytes supplemented with palm-tree kale extracts. Data are expressed as percent of unsupplemented (US) cells (dotted line). Statistical analysis was by one day ANOVA (panel A n.s. not significant; panel B p $<0.001$ ), with Dunnett's test for comparison with US cells ( ${ }^{*} \mathrm{p}<0.05$; ${ }^{* *} \mathrm{p}<0.01$; p $<0.001)$.

tion; conversely, supplementation at the highest dose caused a significant increase in cell proliferative activity in the order HD-0N $>$ HD-160N $>$ TD-160N (Figure 1(b)).

Upon the $\mathrm{H}_{2} \mathrm{O}_{2}$-treatment a significant increase in LDH release $(+17.3 \%)$, and a significant decrease in cell proliferative activity $(-22.5 \%)$ was detected in US cells. This increase of LDH release was totally prevented in cells supplemented with TC, or palm-tree kale extracts at both concentrations; in most of kale supplemented cell treatments LDH leakage was even lower than in US cells in basal condition (Figure 2(a)).

In stressed cells TC, as well as the highest concentration of HD-0N and HD-160N kale extracts, totally prevented the decrease in proliferative activity. On the contrary supplementation with TD-160N and with the lower 
concentration of all extracts was ineffective (Figure 2(b)).

\section{Discussion}

High consumption of fruit and vegetables has been proven to be associated with lower incidence and mortality rate of various chronic diseases such as cancer [22,23], cardiovascular diseases [24-26], and inflammatory-associated conditions [27] by several human cohort and casecontrol studies. Cardiovascular disease causes 1.8 million premature deaths annually in Europe [28] and 10 million in United States [29]. The majority of these deaths are preventable with some modest dietary improvements, like increased intake of fruits and vegetables [29-31].

In addition to fibers, vitamins and minerals present in fruit and vegetables, phytochemicals may contribute to the protective effects; many plant bioactives have antioxidant capacity, and may protect cells against the oxidative damage caused by reactive oxygen species. The
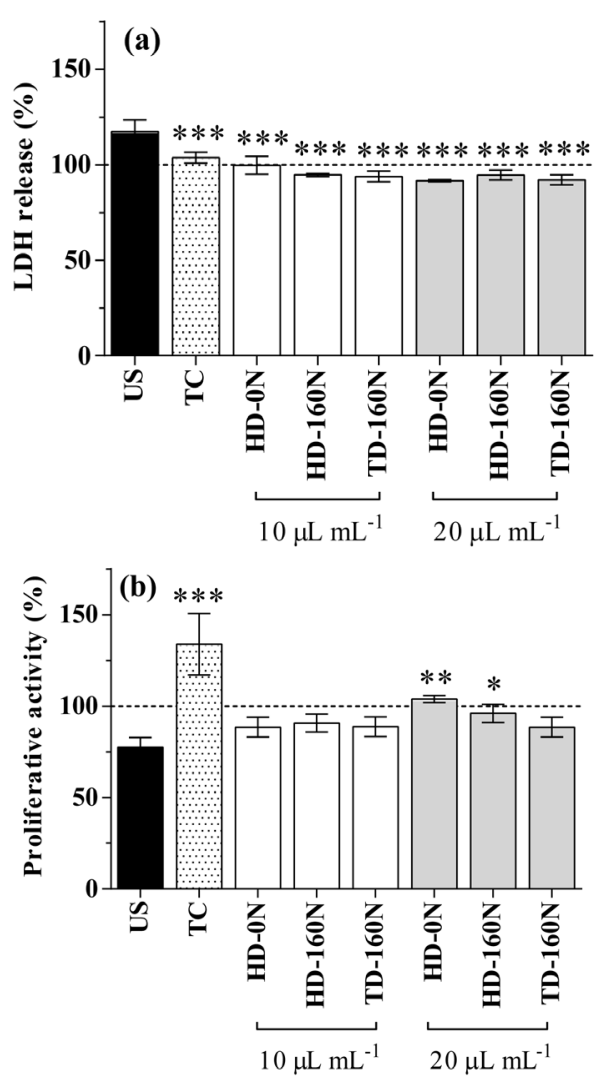

Figure 2. LDH release (A) and proliferative activity $(B)$ in $\mathrm{H}_{2} \mathrm{O}_{2}$-treated cardiomyocytes supplemented with $\alpha$-tocopherol (TC) or palm-tree kale extracts. Data are expressed as percent of non-stressed unsupplemented (US) cells (dotted line). Statistical analysis was by one day ANOVA (panel A p $<0.001$; panel B $p<0.001$ ), with Dunnett's test for comparison with US cells $\left({ }^{*} \mathrm{p}<0.05 ;{ }^{* *} \mathrm{p}<0.01 ;{ }^{* * *} \mathrm{p}<\right.$ 0.001). recommendation to increase the daily intake of fruit and vegetables is often disregarded, so a way to enhance the intake of phytochemicals could be to increase their content in fresh vegetables by utilizing crop production practices, e.g. selection of species and cultivars, nutrition and water supply, sowing and harvest time [2].

In order to evidence the impact of agronomic techniques on the phytochemical content we chose kale as model plant since Italian "black" kale (Brassica oleracea L. var. acephala DC), as well as broccoli, has been reported to possess the highest content total phenolics and flavonoids within the Brassica family [16]. Phytochemical content in plant varies due to cultivar, maturity at harvest, soil and water state, climate (e.g. temperature and radiation level), and postharvest treatments $[3,13]$; in this study we tested kale extracts derived from plant of the same cultivar, grown in the same conditions. In this way we could focus on two agronomic variables only, i.e. plant density and nitrogen fertilization. Palm-tree kale was already demonstrated as suitable to grow at high plant density, according to industrialized production systems [9]. Nitrogen uptake, which is genetically determined, is higher in Brassica than in many other food crops [32].

No difference in phenolic content was detected between extracts of palm-tree kale grown at the same plant density (high density), differing in nitrogen fertilization only (0 and $160 \mathrm{~kg} \cdot \mathrm{ha}^{-1}$, respectively). Although it has been reported that increased nitrogen availability may decrease the levels of phenolic compounds [33], and that minimized nitrogen fertilization is necessary to obtain high phenolics content in Brassica oleracea var. costata [34], our data suggest that nitrogen fertilization is not a determinant of phenolic concentration, at least in palmtree kale and in the tested conditions. On the contrary, plant density seemed particularly important in determining the phenolic content, TD-160N palm-tree kale extract having a lower TPC than HD-160N one. The influence of plant density on phenolic content could be the result of factors related to plant competition, as light, nutrients, and water [35].

Supplementation with palm-tree kale extracts to cultured cardiomyocytes had no toxic effect in basal condition, and increased cell proliferative activity. Kale extracts have been reported to inhibit proliferation of several cancer cell lines [36,37]; it is worth noting that primary cardiomyocytes are not neoplastic cells, and normal cells can behave differently from neoplastic ones. Thus, in our case, the kale pro-proliferative effect should be considered positively.

Kale extracts supplementation counteracted the adverse effects of hydrogen peroxide exposure, protecting cells from oxidative damage. Regarding LDH release, the 
effect was similar for all extracts at both tested concentrations, and comparable to the effect of TC supplementation. The reduction of the proliferative activity induced by the oxidative stress was prevented in TC- and in kale-supplemented cells. This protective effect was dose-dependent for HD-0N and HD-160N extracts, while TD-160N one was ineffective, in agreement with the lower TAC and TPC observed in vitro.

\section{Conclusions}

The effect of different agronomic factors on edible plant bioactive content and the consequent impact on the plant effectiveness in biological systems is poorly studied. Our results indicate that agronomic techniques, particularly plant density, have an impact on the protective effects of palm-tree kale in cells via a modification of total phenolics and antioxidant activity in the plant.

This research was not aimed to the demonstration of a preventive dietary effect of palm-tree kale, since we acknowledge that results in whole organisms may diverge from those in cultured cells because of bioavailability and metabolism of bioactive components. The results herein reported can be useful for the selection of production techniques that are able to produce edible vegetables with higher functional activity, and evidence of the advantage of screening agronomic variables prior to select plant food for clinical studies. The phytochemical content of plant food varies widely according to varieties, environmental and agronomic characteristics, but these differences are neglected while studying the health effects of foods, and could be one reason for discrepancies among the different trials concerning the same food.

There is therefore the need to study the food domain as a whole with the nutrition domain, and to integrate all results in order to have an overall "foodomics" vision allowing the improvement of health and well-being [38].

\section{Acknowledgements}

This study was funded by the European Community's Seventh Framework Program (FP7/2007-2013) under agreement No. 227118, project BaSeFood, and by the Italian Ministry of Education, University and Research (MIUR; PRIN project 2005). The authors thank Dr. Roberta Neri for skillful assistance during fieldwork.

\section{REFERENCES}

[1] N. Hounsome, B. Hounsome, D. Tomos and G. EdwardsJones, "Plant Metabolites and Nutritional Quality of Vegetables,” Journal of Food Science, Vol. 73, No. 4, 2008, pp. R48-R65.

http://dx.doi.org/10.1111/j.1750-3841.2008.00716.x

[2] M. Schreiner, "Vegetable Crop Management Strategies to
Increase the Quantity of Phytochemicals," European Journal of Nutrition, Vol. 44, No. 2, 2005, pp. 85-94. http://dx.doi.org/10.1007/s00394-004-0498-7

[3] A. Podsędek, "Natural Antioxidants and Antioxidant Capacity of Brassica Vegetables: A Review," LWTFood Science and Technology, Vol. 40, No. 1, 2007, pp. 1-11. http://dx.doi.org/10.1016/j.lwt.2005.07.023

[4] B. Watzl and C. Leitzmann. "Other Biologically Active Substances in Plant foods: Phytochemicals,” In: J. Mann and S. Truswell, Eds., Essentials of Human Nutrition, Oxford University Press, Oxford, 2012, pp. 254-264.

[5] P. M. Kris-Etherton, K. D. Hecker, A. Bonanome, S. M. Coval, A. E. Binkoski, K. F. Hilpert, A. E. Griel and T. D. Etherton, "Bioactive Compounds in Foods: Their Role in the Prevention of Cardiovascular Disease and Cancer," The American Journal of Medicine, Vol. 113, No. 9, 2002, pp. 71-88.

http://dx.doi.org/10.1016/S0002-9343(01)00995-0

[6] P. Soengas, M. E. Cartea, M. Francisco, T. Sotelo and P. Velasco, "New Insights into Antioxidant Activity of Brassica Crops,” Food Chemistry, Vol. 134, No. 2, 2012, pp. 725-733.

http://dx.doi.org/10.1016/j.foodchem.2012.02.169

[7] E. G. Rogan, "The Natural Chemopreventive Compound Indole-3-Carbinol: State of the Science," In Vivo, Vol. 20, No. 2, 2006, pp. 221-228.

[8] R. H. Liu, "Health Benefits of Fruit and Vegetables Are from Additive and Synergistic Combinations of Phytochemicals," The American Journal of Clinical Nutrition, Vol. 78, Suppl. 3, 2003, pp. 517S-520S.

[9] L. F. D'Antuono and R. Neri, “Characterisation and Potential New Uses of Palm Tree Kale (Brassica Oleracea L., ssp. Acephala DC, Var. Sabellica L.)," Acta Horticulturae, Vol. 459, 1998, pp. 97-104.

[10] A. C. Kurilich, G. J. Tsau, A. Brown, L. Howard, B. P. Klein, E. H. Jeffery, M. Kushad, M. A. Wallig and J. A. Juvik, "Carotene, Tocopherol, and Ascorbate Contents in Subspecies of Brassica oleracea,” Journal of Agricultural and Food Chemistry, Vol. 47, No. 4, 1999, pp. 15761581. http://dx.doi.org/10.1021/jf9810158

[11] E. Sikora, E. Cieślik, T. Leszczyńska, A. Filipiak-Florkiewicz and P. M. Pisulewski, "The Antioxidant Activity of Selected Cruciferous Vegetables Subjected to Aquathermal Processing,” Food Chemistry, Vol. 107, No. 1, 2008, pp. 55-59.

http://dx.doi.org/10.1016/j.foodchem.2007.07.023

[12] S. F. Hagen, G. I. A. Borge, K. A. Solhaug and G. B. Bengtsson, "Effect of Cold Storage and Harvest Date on Bioactive Compounds in Curly Kale (Brassica oleracea L. var. acephala)," Postharvest Biology and Technology, Vol. 51, No. 1, 2009, pp. 36-42. http://dx.doi.org/10.1016/j.postharvbio.2008.04.001

[13] M. Zietz, A. Weckmuller, S. Schmidt, S. Rohn, M. Schreiner, A. Krumbein and L. W. Kroh, "Genotypic and Climatic Influence on the Antioxidant Activity of Flavonoids in Kale (Brassica oleracea var. sabellica),” Journal of Agricultural and Food Chemistry, Vol. 58, No. 4, 2010, pp. 2123-2130. http://dx.doi.org/10.1021/jf9033909 
[14] F. Ferioli, E. Giambanelli, L. F. D’Antuono, H. S. Costa, T. G. Albuquerque, A. S. Silva, O. Hayran and B. Koçaoglu, "Comparison of Leafy Kale Populations from Italy, Portugal, and Turkey for Their Bioactive Compound Content: Phenolics, Glucosinolates, Carotenoids, and Chlorophylls," Journal of the Science of Food and Agriculture, Vol. 93, No. 14, 2013, pp. 3478-3489. http://dx.doi.org/10.1002/jsfa.6253

[15] D. J. Kornbrust and R. D. Mavis, "Relative Susceptibility of Microsomes from Lung, Heart, Liver, Kidney, Brain and Testes to Lipid Peroxidation: Correlation with Vitamin E Content,” Lipids, Vol. 15, No. 5, 1980, pp. 315322. http://dx.doi.org/10.1007/BF02533546

[16] D. Heimler, P. Vignolini, M. G. Dini, F. F. Vincieri and A. Romani, "Antiradical Activity and Polyphenol Composition of Local Brassicaceae Edible Varieties," Food Chemistry, Vol. 99, No. 3, 2006, pp. 464-469. http://dx.doi.org/10.1016/j.foodchem.2005.07.057

[17] R. Re, N. Pellegrini, A. Proteggente, A. Pannala, M. Yang and C. Rice-Evans, "Antioxidant Activity Applying an Improved ABTS Radical Cation Decolorization Assay," Free Radical Biology \& Medicine, Vol. 26, No. 9-10, 1999, pp. 1231-1237. http://dx.doi.org/10.1016/S0891-5849(98)00315-3

[18] F. Danesi, S. Elementi, R. Neri, M. Maranesi, L. F. D'Antuono and A. Bordoni, "Effect of Cultivar on the Protection of Cardiomyocytes from Oxidative Stress by Essential Oils and Aqueous Extracts of Basil (Ocimum basilicum L.)," Journal of Agricultural and Food Chemistry, Vol. 56, No. 21, 2008, pp. 9911-9917. http://dx.doi.org/10.1021/jf8018547

[19] S. Yagev, M. Heller and A. Pinson, "Changes in Cytoplasmic and Lysosomal Enzyme Activities in Cultured Rat Heart Cells: The Relationship to Cell Differentiation and Cell Population in Culture,” In Vitro, Vol. 20, No. 12, 1984, pp. 893-898. http://dx.doi.org/10.1007/BF02619662

[20] C. Legrand, J. M. Bour, C. Jacob, J. Capiaumont, A. Martial, A. Marc, M. Wudtke, G. Kretzmer, C. Demangel, D. Duval, et al., "Lactate Dehydrogenase (LDH) Activity of the Cultured Eukaryotic Cells as Marker of the Number of Dead Cells in the Medium,” Journal of Biotechnology, Vol. 25, No. 3, 1992, pp. 231-243. http://dx.doi.org/10.1016/0168-1656(92)90158-6

[21] T. Mosmann, "Rapid Colorimetric Assay for Cellular Growth and Survival: Application to Proliferation and Cytotoxicity Assays,” Journal of Immunological Methods, Vol. 65, No. 1-2, 1983, pp. 55-63. http://dx.doi.org/10.1016/0022-1759(83)90303-4

[22] R. Doll, “An Overview of the Epidemiological Evidence Linking Diet and Cancer," The Proceedings of the Nutrition Society, Vol. 49, No. 2, 1990, pp. 119-131. http://dx.doi.org/10.1079/PNS19900018

[23] T. J. Key, "Fruit and Vegetables and Cancer Risk,” British Journal of Cancer, Vol. 104, No. 1, 2011, pp. 6-11. http://dx.doi.org/10.1038/sj.bjc.6606032

[24] S. N. Bhupathiraju, N. M. Wedick, A. Pan, J. E. Manson, K. M. Rexrode, W. C. Willett, E. B. Rimm and F. B. Hu, "Quantity and Variety in Fruit and Vegetable Intake and
Risk of Coronary Heart Disease,” The American Journal of Clinical Nutrition, Vol. 98, No. 6, 2013, pp. 15141523. http://dx.doi.org/10.3945/ajcn.113.066381

[25] L. M. Oude Griep, J. M. Geleijnse, D. Kromhout, M. C. Ocke and W. M. Verschuren, "Raw and Processed Fruit and Vegetable Consumption and 10-Year Coronary Heart Disease Incidence in a Population-Based Cohort Study in the Netherlands," PLoS One, Vol. 5, No. 10, 2010, Article ID: e13609.

[26] L. Dauchet, P. Amouyel, S. Hercberg and J. Dallongeville, "Fruit and Vegetable Consumption and Risk of Coronary Heart Disease: A Meta-Analysis of Cohort Studies," The Journal of Nutrition, Vol. 136, No. 10, 2006, pp. 25882593.

[27] N. Khan, M. Monagas, M. Urpi-sarda, R. Llorach and C. Andres-Lacueva, "Contribution of Bioactive Foods and Their Emerging Role in Immunomodulation, Inflammation, and Arthritis,” In: R. R. Watson and V. R. Preedy, Eds., Bioactive Food as Dietary Interventions for Arthritis and Related Inflammatory Diseases, Academic Press, San Diego, 2013, pp. 43-65. http://dx.doi.org/10.1016/B978-0-12-397156-2.00256-8

[28] T. Jorgensen, S. Capewell, E. Prescott, S. Allender, S. Sans, T. Zdrojewski, D. De Bacquer, J. de Sutter, O. H. Franco, S. Logstrup, M. Volpe, S. Malyutina, P. Marques-Vidal, Z. Reiner, G. S. Tell, W. M. Verschuren, D. Vanuzzo and on Behalf of the PEP Section of the EACPR, "Population-Level Changes to Promote Cardiovascular Health," European Journal of Preventive Cardiology, Vol. 20, No. 3, 2013, pp. 409-421. http://dx.doi.org/10.1177/2047487312441726

[29] D. Mozaffarian and S. Capewell, "United Nations' Dietary Policies to Prevent Cardiovascular Disease,” BMJ, Vol. 343, 2011, Article ID: d5747. http://dx.doi.org/10.1136/bmj.d5747

[30] P. Scarborough, K. E. Nnoaham, D. Clarke, S. Capewell and M. Rayner, "Modelling the Impact of a Healthy Diet on Cardiovascular Disease and Cancer Mortality,” Journal of Epidemiology and Community Health, Vol. 66, No. 5, 2012, pp. 420-426. http://dx.doi.org/10.1136/jech.2010.114520

[31] H. Boeing, A. Bechthold, A. Bub, S. Ellinger, D. Haller, A. Kroke, E. Leschik-Bonnet, M. J. Müller, H. Oberritter, M. Schulze, P. Stehle and B. Watzl, "Critical Review: Vegetables and Fruit in the Prevention of Chronic Diseases,” European Journal of Nutrition, Vol. 51, No. 6, 2012, pp. 637-663. http://dx.doi.org/10.1007/s00394-012-0380-y

[32] P. Malagoli, P. Laine, L. Rossato and A. Ourry, "Dynamics of Nitrogen Uptake and Mobilization in Field-Grown Winter Oilseed Rape (Brassica napus) from Stem Extension to Harvest. II. An ${ }^{15} \mathrm{~N}$-Labelling-Based Simulation Model of N Partitioning between Vegetative and Reproductive Tissues," Annals of Botany, Vol. 95, No. 7, 2005, pp. 1187-1198. http://dx.doi.org/10.1093/aob/mci131

[33] J. Witzell and A. Shevtsova, "Nitrogen-Induced Changes in Phenolics of Vaccinium myrtillus-Implications for Interaction with a Parasitic Fungus,” Journal of Chemical Ecology, Vol. 30, No. 10, 2004, pp. 1937-1956. 
http://dx.doi.org/10.1023/B:JOEC.0000045587.75128.a4

[34] C. Sousa, D. M. Pereira, J. A. Pereira, A. Bento, M. A. Rodrigues, S. Dopico-Garcia, P. Valentao, G. Lopes, F. Ferreres, R. M. Seabra and P. B. Andrade, "Multivariate Analysis of Tronchuda Cabbage (Brassica oleracea L. var. costata DC) Phenolics: Influence of Fertilizers," Journal of Agricultural and Food Chemistry, Vol. 56, No. 6, 2008, pp. 2231-2239. http://dx.doi.org/10.1021/jf0730410

[35] M. Björkman, I. Klingen, A. N. Birch, A. M. Bones, T. J. Bruce, T. J. Johansen, R. Meadow, J. Mølmann, R. Seljåsen, L. E. Smart and D. Stewart, "Phytochemicals of Brassicaceae in Plant Protection and Human HealthInfluences of Climate, Environment and Agronomic Practice,” Phytochemistry, Vol. 72, No. 7, 2011, pp. 538-556. http://dx.doi.org/10.1016/j.phytochem.2011.01.014
[36] H. Olsen, S. Grimmer, K. Aaby, S. Saha and G. I. Borge, "Antiproliferative Effects of Fresh and Thermal Processed Green and Red Cultivars of Curly Kale (Brassica oleracea L. Convar. acephala var. sabellica),” Journal of Agricultural and Food Chemistry, Vol. 60, No. 30, 2012, pp. 7375-7383. http://dx.doi.org/10.1021/jf300875f

[37] D. Boivin, S. Lamy, S. Lord-Dufour, J. Jackson, E. Beaulieu, M. Côté, A. Moghrabi, S. Barrette, D. Gingras and R. Béliveau, "Antiproliferative and Antioxidant Activities of Common Vegetables: A Comparative Study,” Food Chemistry, Vol. 112, No. 2, 2009, pp. 374-380. http://dx.doi.org/10.1016/j.foodchem.2008.05.084

[38] F. Capozzi and A. Bordoni, "Foodomics: A New Comprehensive Approach to Food and Nutrition," Genes \& Nutrition, Vol. 8, No. 1, 2013, pp. 1-4. http://dx.doi.org/10.1007/s12263-012-0310-x 